\title{
Madhyamakāvatāa and Prasannapadā
}

\author{
YoneZAWA Yoshiyasu
}

\section{Preamble}

The Madhyamakāvatāra (MA) and the Prasannapadā (Pras), a commentary on Nāgārjuna's Mülamadhyamakakārikā (MMK), are the two most representative treatises by Candrakīrti (ca. 600-650), who recognized himself as a Mādhyamika. The MA predates the Pras since the former is quoted in the latter. Focusing on the MA's final five verses and the Pras's initial four verses, the present paper intends to point out a contrast between these treatises.

\section{A Structure of the Madhyamakāvatāra}

Before quoting the verses in question, a few remarks should be made concerning the structure of the MA.')

\subsection{Ten Resolutions}

In the Tibetan MA, we find the chapter colophons corresponding to ten resolutions (cittotpāda). ${ }^{2}$ As far as the four verses from the seventh to the ninth resolution - serially numbered in LVP's Tibetan Madhyamakāvatārabhāsya (MABh) ${ }^{3)}$ edition — are concerned, the chapter divisions take place in the middle of the first and the fourth verses, respectively. ${ }^{4)}$

The first verse reads as follows:

kṣaṇe kṣaṇe caiṣa nirodham asyām dūramigamāyām pratipadyamānạ̣ |

upāyasatpāramitāptadīptị̣ muhurmuhuḥ prāk kuśalādhikāptau ||

In the middle of this verse, the seventh resolution ends with "splendor acquired through the excellent perfection of efficient strategies (upāyasatpāramitāptadīptih),' while the eighth begins with 'for the sake of constantly attaining the increase of previous wholesome [deeds] (muhurmuhuh prāk kuśalādhikāptau)' and ends within the fourth verse which reads as follows: 
niruddhạ samisāro daśa tu vaśitāḥ prāptim agaman svam ātmānam tābhị̣ kathayati vicitram bhavagatau |

navamyām saṁśuddhim vrajati hi balan tasya sakalam tathā samividdharmām svaguṇapariśuddhāmśs ca labhate \|

The first half verse, 'samsāra has stopped, but having attained the ten powers, by virtue of these he reveals himself variously in the state of existence,' belongs to the eighth resolution, whereas the latter half verse, 'at the ninth [stage], all of his powers become fully purified, and likewise, [he = a bodhisattva] obtains [the four] special knowledges purified by [his] own characteristics,' describes the ninth resolution.

Notably, there are extra verses after the tenth resolution.

\subsection{Contents after the Ten Resolutions}

After the comments on the tenth resolution, the Sanskrit MABh runs as follows:

idānīm ādyam் cittotpādam ārabhya tadguṇasamikhyādhigamam adhikṛtyāha ...

'Now, beginning from the initial resolution, taking as [his] topic the understanding of the number of their qualities, he (= Candrakīrti) says, ....'

The comments on nine verses addressing the numbers of the qualities on the ten [bodhisattva] stages ends as follows:

uktā daśabhūmayo guṇapratilambhatạ

'The ten stages have been explained from the point of view of the attainment of qualities.'

The Tibetan text reads differently, as follows:

byang chub sems dpa'i sa'i yon tan bstan pa bshad zin to

'The qualities of the Bodhisattva stage have been explained.'

The text continues as follows:

atạ param buddhabhūmẹ kimcinmātraguṇodbibhāvayiṣayā Buddham Bhagavantam adhikṛtya stutyupasamināreṇāha ...

'Hereafter, with regard to the Buddha, the Exalted One, with the intent to express a small measure of the qualities of the Buddha stage, he (Candrakīrti) says, by way of summarizing praise,'

From the above quotations, it is clear that the contents of the MA after the ten resolutions are shifted to both Bodhisattva and Buddha stages. LVP's Tibetan MABh edition, moreover, restarts the numbering for the final five verses since they are dedicated to Nāgārjuna. ${ }^{5)}$ 


\subsection{On the Chapter Divisions}

In terms of contents, the MA comprises thirteen topics, namely, ten resolutions, the qualities on both the Bodhisattva and Buddha stages, and homage to Nāgārjuna. However, it is not always certain whether these topics correspond to the chapters in the MA, since it needs to be explained why the chapter divisions from the seventh to ninth take place in the middle of the verses.

In the Sanskrit MABh, the chapter colophons with the indication in the MA (madhyamakāvatāre)' are found only from the first to the fifth resolution. ${ }^{6}$ The Sanskrit notes on the MABh in the *Lakșanațīkā (*Lakṣ), moreover, indicates chapters 1-5 only. These facts suggest that the material in the MA(Bh) from the sixth resolution onwards was not considered to be divided.

For the purpose of the present paper, it suffices here to state that a careful examination is required for determining the MA's chapter divisions.

\section{The Final Five Verses in the Madhyamakāvatāra}

The final five verses in the MA, dedicated to Nāgārjuna, run as follows:

śāstrān madhyamakād eșā prakriyodvṛtya varṇitā

yathāgamam yathāmnāyam bhikṣuṇā Candrakīrtinā $\|$ [1]

'This doctrine (prakriyā), having been selected from the Madhyamaka Sāstra, is described by the mendicant Candrakīrti, following authoritative testimony (ägama) and tradition (āmnāya).'

ito 'nyatra na dharmo 'yam yathâsti prakriyā tathā

ihatyānyatra nāstīti vyavasyantu vicakșanāạ $\|[2]^{9)}$

'The clear-sighted ones should be convinced that in the same way that this Dharma does not exist anywhere else than here, the doctrine here (ihatyā) does not exist elsewhere.'

Nāgārjunorutaradhīhradavarṇabhītya tyaktāni yāni sumatāni janena dūrāt

tatkārikākumudakuḍmalabodhatoyair āsāạ prapūrayati samprati Candrakīrtị $\|[3]^{10)}$

'Frightened of the color of the lake of Nāgārjuna's expansive wisdom $(d h \bar{l})$, people, at a distance, have abandoned the excellent tenet systems (sumatāni). Candrakīrti now fulfils [their] wishes with the water that causes the water-lily buds of his verses [of the MA] to bloom.'

prāgabhyāsata eva tattvam uditam bhīmam gabhīram jano

yāyān niścayatạ śrute 'pi ca mahaty anyo na yāyād idam

tasmād anyamate svabuddhiracitā dṛșțāpi tāh prakriyāh

ātmodbhāsimateșv iva tyaja matād asmāt parasmin matim $\|[4]^{11)}$

'Just on account of previous practice, a person would definitely understand the frightening and 
profound truth that has been explained, but others, even though greatly learned, would not understand this [truth]. Therefore, having seen those doctrines that were fabricated by their own understanding (svabuddhiracitā) in the doctrines of others, give up, as in the tenet system which illuminates the Self (Ātman), [your] esteem (mati) in regard to the other [tenet system] over our tenet system.'

prāptam puṇami sumatakathanād ārya-Nāgārjunasya

prāptāśāntam śaradựunibham kleśakṛ̣ṇe manạ̣khe

cintāhau vā phaṇamaṇinibham yan mayā tena lokas

tattvam buddhvā tvaritam akhilami saugatim yāntu bhūmim $\|[5]^{12)}$

'By the merit, which extends to the end of space, that I have obtained from the exposition of the excellent tenet system of the Noble Nāgārjuna, [merit which is], like autumn stars in the sky of the mind darkened by defilements, or like the jewel in the hood of the serpent of the mind, may the world, having realized reality, completely [and] quickly proceed quickly to the stage of the One Well Gone.'

\subsection{The Other Occurrences of Prakriyā in the Madhyamakāvatāra}

In the verses quoted above, one of the crucial terms is 'doctrine (prakriya $\bar{a}$ ).' In the MA, the term is also found in the following verses:

dharmān sa gambhīratarān avaiti yathāgamenāpi ca yuktitaś ca |

tathāryanāgārjunan̄ititas tān yathāsthitaprakriyayā bravīmi $\|[\text { VI.3 }]^{13)}$

'Just as he (i.e., Nāgārjuna) understands that the elements (dharmas) have the extremely profound [natures of dependent arising] by means of authoritative testimony (ägama) as well as reasoning (yukti), so do I explain them by means of the doctrine as it stands (yathāsthitaprakriyā), following the Noble Nāgārjuna.'

evam̉ jñātvā prakriyām āgamasya vyākhyātārtham yac ca neyārtham uktam |

sūtram buddhvā nīyatām yan na tattvami nītārtham ca jñāyatām śūnyatārtham $\|$ [VI.97] ${ }^{14)}$

'Having known the doctrine (prakriy $\bar{a}$ ) of the authoritative testimony ( $\bar{a}$ gama) in this way and having understood that a scripture which has a meaning that is explained [and] is not truth, is said to have a provisional meaning (neyārtha), and should be interpreted; and [scripture] with the meaning of the emptiness should be known as having definitive meaning (nītärtha).'

ātmā tīrthyaị̣ kalpyate nityarūpo 'kartā bhoktā nirguṇo niṣkriyaś ca |

kamicit kamicid bhedam āśritya tasya bhedam yātāḥ prakriyās tīrthikānām $\|\left[\right.$ VI.121] ${ }^{15)}$

'The Self (Ātman) is imagined by the outsiders as having a permanent nature, a non-agent, the enjoyer, without characteristics, and without activity. The doctrines of the outsiders concerning it (= the Self) have been differentiated in reliance on trivial differences.'

In the MA, it is noticed that the denotation of prakriy $\bar{a}$ is not limited to the Madhyamaka but also to other philosophical schools. Therefore, it can be concluded that doctrines 
other than the Madhyamaka are taken into consideration when this term is used in the MA.

\section{The Initial Four Verses in the Prasannapada}

Like the final five verses in the MA, the initial four verses in the Pras are also dedicated to Nāgārjuna. They run as follows:

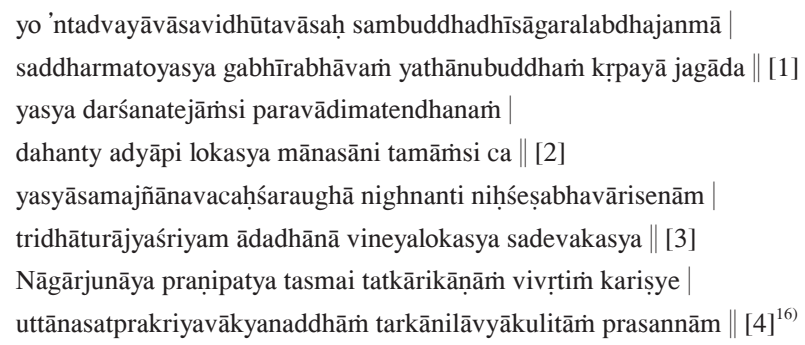

'Having bowed respectfully to Nāgārjuna, whose abode is removed from the dwelling of the two extremes, who attained his birth in the ocean of wisdom for the completely awakened one, who speaks, out of compassion, the profoundness of the water of correct Dharma just as he conceived [it], whose flames of the view consume even today the fuel of others' tenet system and the mental darkness of the world, whose words from unequal knowledge like showers of arrows destroy existence like the entire hostile army, [and] establish sovereignty in the three realms for living beings to be guided and the gods, I shall compose a commentary to his verses, which is inlaid with understandable sentences in which the correct doctrine [is exposed], undisturbed by the winds of logics, and of clarity. ${ }^{, 17)}$

Although the Pras reads ${ }^{\circ}$ rakriya ${ }^{\circ}$, ${ }^{*}$ Laks glosses with prakriy $\bar{a}^{18)}$ The terms such as 'wisdom (dhî),' 'water (toya), 'profound (gabhīra),' '(the) other (para),' 'tenet system (mata), 'living beings (loka), 'Nāgārjuna,' and 'doctrine (prakriyā)' are also found in the final five verses in the MA. The figurative expressions such as the mental darkness (mānasāni tamämsi) remind us of the MA's final verse. Based on this close relationship, one could imagine that Candrakīrti might have composed the Pras immediately after the MA.

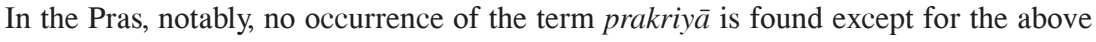
homage verse and the quotation of MA VI.121. Taking the usages of the term prakriya in the MA into consideration, it can be presumed that the MA is intended for general readers whereas the main targets of the Pras are the followers of the Madhyamaka doctrine.

\subsection{Prakriyā in the Madhyamakaśāstrastuti}

Incidentally, the term prakriyā is found in the Madhyamakaśāstrastuti (MŚS) consisted of 
fourteen verses found at the end of the Pras. ${ }^{19)}$ The verse in question runs as follows:

kṛtvā vṛttim imām anākulapadām satprakriyām ādarāt

śrāddhānām sudhiyām ca niścayavidhau yuktyāgamāpāśrayām |

yat punyam mama śūnyateva vipulam tenaiva loko 'khilas

tyaktvā dṛ̣țigaṇam prayātu padavīm sarvaprapañcacchidām $\|$ MŚS $13^{20)}$

'Having composed this commentary zealously, which has understandable phrases and the correct doctrine, within the way of ascertainment for the sake of the faithful and wise persons on the basis of reasoning and authoritative testimony, may living beings, by means of my broad merits like emptiness, having abandoned the group of [wrong] views, proceed to the path in which all manifoldness has ceased.'

This usage of the term prakriya seems to follow the third pada of the fourth verse in the Pras, i.e., which is inlaid with understandable sentences in which the correct doctrine [is exposed] (uttānasatprakriyavākyanaddhāmi)' quoted above.

The verses of the MŚS are also dedicated to Nāgārjuna just as the final five verses in the MA and the initial four verses in the Pras. In the MŚS, moreover, it is noted that not only the treatises attributed to Nāgārjuna (v.10) are enumerated but also the names of the Madhyamaka masters (v.6 and 11) are referred to. These references might support a hypothesis that the Pras is intended for Madhyamaka followers.

\section{A Conclusion}

First, the present paper poses a question about the chapter divisions in the MA. Although the MA has thirteen topics, namely, ten resolutions, the merits in both Bodhisattva and Buddha stages, and the homage verses to Nāgārjuna, it is necessary to examine whether these topics correspond to the chapter division of MA or not. Besides the division from the seventh to ninth resolution, the chapter colophons in the Sanskrit MABh should be carefully examined to determine this.

Next, the final five verses in the MA and the initial four verses in the Pras, both of which are dedicated to Nāgārjuna, are quoted together with tentative translations. The fact that the same terms, namely, 'wisdom (dhì), ' water (toya), 'profound (gabhīra), '(the) other (para), 'tenet system (mata),' 'living beings (loka),' 'Nāgārjuna,' and 'doctrine (prakriyāa)' are found therein shows a close relationship between both treatises. As far as the term prakriy $\bar{a}$ is concerned, however, there are no occurrences in the Pras except for the homage verse and the quotation from MA VI.121. This usage might imply that the MA is intended 
for the general readers, whereas the Pras is limited to the Mādhyamikas. This hypothesis might be supported by the MŚS.

I benefitted from attending the reading sessions of the Sanskrit MA(Bh) together with Prof. Katsura Shōryū, Dr. Li Xuezhu, and Prof. Kano Kazuo in Kyoto on September 2018 and 2019. Thanks are due to all participants of the Madhyamaka Workshop organized by Dr. Anne MacDonald in Vienna the first week of March 2020. Moreover, I wish to express my gratitude to Prof. Nagashima Jundō, Prof. Kano, and Dr. MacDonald for making a number of helpful suggestions and comments on the present paper. Needless to say, I take full responsibility for any surviving errors in this paper.

\section{Notes}

1) See also Matsumoto 2010, (28)-(32).

2) See D 3861: 202b1, 203a1, 203b4-5, 203b6, 203b7, 215a5, 215a6, 215b1, 2152, 215b3-4.

3) The MA's Sanskrit text is based on the Sanskrit manuscript of the MABh, preserved at the Potala Palace in Lhasa. Concerning the manuscript, see Li 2015, 2; Yonezawa 2019, 46-47.

4) See also LVP 1907-1912 [1970], 343.15 and 348.13.

5) These five verses in Tibetan (LVP. 1907-1912 [1970], 406-409) are translated as 'Epilogue' by Huntington 1989, 196. See also Ogawa 1975 and Uryūzu and Nakazawa 2012, 340-344.

6) MABh MS 9a1-2, 12b1, 16b3, 17b5, and 18b4.

7) The Sanskrit notes on the Pras and the Catuhśatakațīa $\bar{a}$ in the *Lakṣ give the chapter numbers 1-27 and 1-16 respectively. Concerning the chapter numbers in the Sanskrit notes on the MABh, see Yonezawa $2019,199,205,210,212$, and 213.

8) The verse numbers follow those of LVP's Tibetan MABh.

9) b: ihatyā for MS. ihartyāं.

10) Concerning the Sanskrit notes in the *Lakṣ, see Yonezawa 2019, 287 (§289).

11) a: 'abhyāsata for MS. 'abhyasata. Concerning the Sanskrit notes in the *Laks, see Yonezawa 2019, $288(\$ 290)$.

12) The reading of the pada b is tentative. b: prāptāsāantam for MS. prāptam śāntam; śaraduḍunibham for MS. śaradudu.u+++tam. c: cintāhau for MS. cittāhau. Concerning the Sanskrit notes in the *Laks, see Yonezawa 2019, 288 (§292).

13) $\mathrm{Li} 2015,4$.

14) Li 2015, 16.

15) This verse is quoted in the Pras. See Niisaku 2016, 112. Cf. LVP 1903-1913 [1970], 344, 5-8 and Li 2015, 19.

16) Cf. MacDonald 2015b, 7-9.

17) MacDonald 2015a, 115-116. The verse numbers are given provisionally.

18) See Yonezawa 2019, $77(\S 2)$.

19) See de Jong 1979. Notably, Sanskrit notes on the Pras in the *Laks deals with the MŚS as a part of the Pras. See Yonezawa 2019, 170-172 (§328-339).

20) See de Jong 1979, 545.

\section{Abbreviations}

*Lakṣ *Lakṣanaṭikkā. See Yonezawa 2019. 
LVP de la Vallée Poussin, Louis.

MA Madhyamakāvatāra. See below.

MABh Madhyamakāvarāra-Bhāṣya. See LVP 1907-1912 [1970], Li 2015, and Yonezawa 2019.

MŚS Madhyamakaśāstrastuti. See de Jong 1979.

Pras Prasannapadā. See LVP 1903-1913 [1970], MacDonald 2015ab, Niisaku 2016, and Yonezawa 2019.

\section{Bibliography}

Huntington, C. W. Jr. and Geshé Namgyal Wangchen. 1989. The Emptiness of Emptiness: An Introduction to Early Madhyamika. Honolulu: University of Hawaii Press.

de Jong, J[an] W[illem]. (1962)1979. “La Madhyamakaśāstrastuti de Candrakīti.” In Buddhist Studies, ed. by Gregory Schopen, 541-550. Berkeley: Asian Humanities Press, A Division of LancasterMiller Publishers.

Li Xuezhu 李学竹. 2015. “Madhyamakāvatāra-kārikā Chapter 6.” Journal of Indian Philosophy 43(1): 1-30. (DOI 10.1007/s10781-014-9227-6 Published online: 22 May 2014.)

LVP. 1907-1912 [1970]. Madhyamakāvatāra par Candrakīrti, Traduction tibétaine. Bibliotheca Buddhica IX. St. Pétersburg: l'Académie impériale des sciences. Reprint Osnabrück: Biblio Verlag.

—. 1903-1913 [1970]. Madhyamakavrttiḥ: Mūlamadhyamakakārikās (Madhyamika-sūtras) de Nāgārjuna avec la Prasannapadā Commentaire de Candrakīrti. Bibliotheca Buddhica IV. St-Pétersbourg: l'Académie impériale des sciences. Reprint Osnabrück: Biblio Verlag.

MacDonald, Anne. 2015a. In Clear Words: The Prasannapadā, Chapter One vol. I Introduction, manuscript description, Sanskrit text. Wien: Verlag der Österreichischen Akademie der Wissenschaften.

- 2015b. In Clear Words: The Prasannapadā, Chapter One vol. II Annotated Translation, Tibetan Text. Wien: Verlag der Österreichischen Akademie der Wissenschaften.

Matsumoto Kōji 松本恒爾. 2010. “Madhyamakāvatāra[Bhāṣya] 7 shō-9 shō shiyaku” Madhyamakāvatāra[Bhāṣya] 7章〜9章試訳. Chisan gakuhō 智山學報 59: (27)-(48).

Niisaku Yoshiaki 新作慶明. 2016. “Purasannapadā dai 18 shō 'ga (ātoman) no kōsatsu' no kenkyū”『プラ サンナパダー』第18章「我（アートマン）の考察」の研究. PhD diss., the University of Tokyo.

Ogawa Ichijō 小川一乗. 1975. “Gesshō no Chūgan Setsu ni tsuite: Nyūchūron no kesshō ni taisuru kaidoku”月称の中観説について：入中論の結章に対する解読. Otani gakuhō大谷学報 55(2): 14-23.

Uryūzu Ryūshin 瓜生津隆真 and Nakazawa Mitsuru 中沢中. 2012. Zenyaku Candrakīrti Nyūchūron 全訳 チャンドラキールティ入中論. Tokyo: Kishin Shobō.

Yonezawa, Yoshiyasu. 2019. “A Tetxtual Study of the *Lakșaṇațīă.” PhD diss., Leiden University. https://openaccess.leidenuniv.nl/handle/1887/79823.

Key words Madhyamakāvatāra, Madhyamakāvatārabhāsya, Prasannapadā, Madhyamakaśāstrastuti, prakriyā

(Associate Professor, Taisho University, Ph.D.) 